\title{
Innovative Potential of the Agrarian Sector of Ukraine: Forming and Efficiency of Realization
}

\author{
Andrii Hutorov ${ }^{1}$, Yurii Lupenko ${ }^{1}$, Svitlana Sherstiuk ${ }^{2}$, Yevhen Ponomarenko ${ }^{3}$, \\ Olena Hutorova ${ }^{2}$, Oksana Yermolenko ${ }^{4}$ \\ ${ }^{I}$ National Scientific Center "Institute of Agrarian Economics", Kyiv, Ukraine \\ ${ }^{2}$ Kharkiv National Agrarian University named after V.V. Dokuchaiev, Kharkiv, Ukraine \\ ${ }^{3}$ LTD Business Center "INGEK", Kharkiv, Ukraine \\ ${ }^{4}$ Simon Kuznets Kharkiv National University of Economics, Kharkiv, Ukraine
}

\begin{abstract}
The innovative development of the primary sector requires accumulation of human capital and technological knowledge. The dynamics of changes and transformations of the innovative potential of the agrarian sector of Ukraine have been analyzed and their status has been estimated. It has been established that Ukraine lacks the strategic vision of the innovative development within agrarian sector of economy, which results in a partial distortion of the essence of scientific, scientific-technical, innovative, and entrepreneurial activities. It has been defined that effective forming and implementation of the innovative potential necessitate the development of mechanisms that would provide regulatory-legal and institutional support to the effective transfer of innovations, proper funding of science and education, material stimulation in the work of scientific and pedagogical staff, renewal of material and technical base necessary for the introduction of scientific-based innovative activity.
\end{abstract}

Keywords - Innovation potential, innovative development, research \& development, agrarian sector of economy, Ukraine.

DOI: $10.18421 /$ TEM103-29

https://doi.org/10.18421/TEM103-29

Corresponding author: Andrii Hutorov,

National Scientific Center "Institute of Agrarian

Economics", Kyiv, Ukraine.

Email: Gutorov.Andrew@gmail.com

Received: 24 March 2021.

Revised: 17 July 2021.

Accepted: 24 July 2021.

Published: 27 August 2021.

(c) BY-NC-ND (C) 2021 Andrii Hutorov et al; published by UIKTEN. This work is licensed under the Creative Commons Attribution-NonCommercial-NoDerivs 4.0 License.

The article is published with Open Access at www.temjournal.com

\section{Introduction}

The agrarian sector of economy is one of the core segments of the national economy, whose development level affects the country's food security, much of the revenues of the state budget, maintaining rural settlements, etc. Further development of the agrarian sector of the economy requires qualitative systemic transformations, which, as the experience of the most developed countries in the world shows, should be based solely on the innovative potential of economic growth. The technological renewal and innovative development of agroindustrial production in Ukraine is one of the strategic directions of innovative activities, defined by the strategies for development of the national economy. The implementation of the set tasks requires forming of qualitatively new productive forces, expressed by the innovative potential for development of the agrarian sector of economy.

At the same time, despite some positive changes and qualitative agrarian transformations, the agrarian sector of national economy does not develop on an innovative model while the innovation processes are characterized by the non-systemic character and deformation of the process phases. In a theoretical aspect, one observes a partial distortion of the content of the innovative potential within a sector, its interpretation as a variety of the resource potential, the aggregated economic potential of agricultural producers, or as a synonym for the scientific and technical potential. This, in turn, leads to incorrect assessments of the magnitude regarding innovative potential of the agrarian sector, which influences the adoption of reasonable managerial decisions. Thus, the issues related to the economic content, such as estimating the size and the dynamics of the innovative potential in development of the agrarian sector of the economy have remained partially resolved and necessitate further scientific research. 


\section{Literature Review}

The fundamentals of the theory and practice of innovative (in the modern sense of the word) development of the agrarian sector of economy were first formed in ancient times with the emergence of economics as a science about household management. At that time, experts noticed that efficient economies attained their advantages mainly due to certain innovations: lower production costs owing to better technology, more productive cattle, successful sales of products, etc. Subsequently, by exploring the impact of machine production on the cost and price of goods, D. Ricardo concluded that under certain conditions and scale of production the replacement of manual labor by machine operations becomes profitable; the price of agricultural products is reduced and this leads to the accumulation of additional profits by landowners due to saving part of the rent [19]. On the other hand, the inventor of the machine or the one who used it for the first time could have an additional benefit because he would, for a certain period, earn more profit [19]. Thus, machine as a new means of production was considered to be an innovation in the economic sense. The Austrian economist J. Schumpeter is thought to be the founder of the innovation theory. He thought that economic development is determined by the "new combinations" of resources, productive forces, as well as production and sale techniques [21]. Schumpeter later termed them as innovations. Such innovations, according to J. Schumpeter, include the introduction of a new product or a new quality of a product, not familiar to most consumers; the introduction of a production new method or a new technique to commercially handle the commodity; the launch of a new market in which a sector of the national economy was not present; opening a new source of supply of raw materials or semi-finished products; the reorganization of the sector, a technique to manage it, its monopolization or de-monopolization [21]. In general, innovation is understood as the newly created (applied) and/or improved competitive technologies, products, or services, as well as organizational and technical solutions of production, administrative, commercial, or other nature, which significantly improve the structure and quality of production and/or social sphere. Innovations are preceded by new designs or innovative products - results of research and/or experimental design development; their derivatives are innovations or innovative products - new competitive goods or services.

Despite the accuracy in defining "innovation", the innovation potential is expressed ambiguously. Thus, the essence of the innovation potential at a microlevel is often defined through a combination of industrial, scientific, financial, marketing, personnel, organizational resources and opportunities that ensure the readiness and ability of an enterprise to carry out the innovative activity at the constant advancement of management systems, taking into consideration the factors of market environment instability [11]. The innovation potential consists of resource, personnel, intellectual, management, production, information, and communication potentials [9]. Somewhat similar is the structure of the innovative potential defined by A. Dziubina: scientific, production-technological, financial, informational, logistical, personnel, and marketing potentials [3]. Scientists T. Zubko, I. Kovshova, N. Ilchenko, V. Laptieva and I. Vavdiichyk generally share the opinion on that the innovative potential of an enterprise represents the existing latent possibilities of attracting and using resources aimed at adopting, introducing innovations that can be involved to achieve the objectives of economic agents; they also concluded that it consists of marketing, information, logistical, personnel, and financial potentials [31]. The innovative potential of an agricultural enterprise is generally identical, according to S. Syrtseva, to the resource potential, highlighting its land, labor, logistical, financial, and informational components [23]. Given the essence, structure, and typology of potential, we do not share the opinion of the above authors regarding the content and structure of the innovative potential of an enterprise. The reasons for this are the methodological differences in the object and subject composition of the potential, as well as the mismatch between the essence of innovations and the cited definitions. Thus, in terms of objects, one highlights the production, innovative, and financial potentials; in terms of subjects, the scientific-technical, management, marketing, logistic, potential, as well potential of the organizational structure of management. Common subject-object attributes are shared by labor, information, and infrastructural potentials of an enterprise. In view of this, in our opinion, the most correct is to consider the definition of the innovative potential of an enterprise given by O. Fedonin, I. Riepina and O. Oleksiuk: the aggregate capacities of an enterprise to generate, accept, and implement new (radical and modified) ideas for its systematic technical, organizational, and managerial renewal [5].

According to $\mathrm{K}$. Moskaliuk, the innovative potential of the agrarian sector covers scientific and technological, marketing, information, intellectual, investment, environmental potentials, as well as the financial support of innovative development [17]. In addition, the degree of innovativeness of the national economy was defined by the scientists as the presence of the critical mass of modern accumulated 
knowledge and the potential level of development of research and research-engineering work from the detection and substantiation of ideas to their commercial implementation [15], [16]. At the same time, we share the opinion by S. Volodin and $\mathrm{O}$. Chekamova who defined the innovative potential as the availability and readiness to use the system of tools and resources to achieve the goals of innovation activities [28]. In addition, in such wording, the concept of innovative potential can be applied at all levels of the hierarchy of an economic system: global (mega level), national economy (macro-level), industry or region (meso-level), economic agent (micro-level), and economic benefits (nano-level).

\section{Methodology}

The theoretical and methodological basis of the research is a dialectical method of cognition and a systematic approach to the study of economic phenomena and processes associated with forming and implementation of innovative potential for the development of the agrarian sector of economy.

To achieve the aim of the paper we used general and special methods: abstract-logical, monographic, deduction and scientific synthesis, historical, comparative and statistical analysis, graphic.

Estimation of innovative potential influence on development of the agrarian sector of economy is carried out by means of production functions [6]. Given the nonlinear nature of the impact of innovation on economic development, we have chosen a power production function of CobbDouglas type:

$$
\mathrm{Q}=\mathrm{a} \cdot \mathrm{RDE}^{\mathrm{b}}
$$

where $Q$ is the gross value added of the agrarian sector of economy; $R D E$ is the $\mathrm{R} \& \mathrm{D}$ expenditures in the field of agricultural sciences; $a$ is the technological coefficient; $b$ is the elasticity coefficient of the production function.

The research period covers 2000-2019.

The information base of the research into the innovative potential of the agrarian sector of
Ukraine's economy is the statistical data by the State Statistics Service of Ukraine [14], the State Enterprise "Ukrainian Institute for Intellectual Property" [24] and annual reports of the National Academy of Agrarian Sciences of Ukraine [1]. The World Bank data were used for comparisons across the globe [25], as well as Eurostat [4] and the World Intellectual Property Organization (WIPO) [29].

\section{Research Results}

Forming the innovative potential, particularly in the agrarian sector, in the information-network economy implies the mechanisms of accumulation of new knowledge. As it is rightly stated in the National Report "Innovative Ukraine - 2020", all the genesis of humanity is a history of the innovative component of socially-divided labor, its subjects, and results. Now is the stage of the intensive deployment of an innovative human essence, which is expressed in the transition from a reproducing to the innovative type of development, where the core process is a movement from the industrial-market to the information-network economy [8]. The essence of the interaction "society - state - economy" in the system of knowledge economy implies the social control and public commitments of the institutions involved in the interaction between the state and businesses as the base of knowledge generation, as well as the implementation of management functions in the area of producing and using knowledge [7]. The main subject of the knowledge economy, its carrier and generator is a networking person who interacts with a large number of information networks, generating the new knowledge and ways of their implementation [10].

The data given by V. Heyets [7] show that the economy of Ukraine corresponds to structures 3rd and 4th; the pace of change in the major macroindicators gives grounds to describe it as the necroindustrial (deindustrialization of the economy's sectors within technological modes 3rd and 4th) (Table 1).

Table 1. Technological mode of Ukrainian economy, \%

\begin{tabular}{|c|c|c|c|c|}
\hline \multirow{2}{*}{ Indicator } & \multicolumn{4}{|c|}{ Technological mode } \\
\hline & 3rd & 4th & 5th & 6th \\
\hline Production volume & 57.9 & 38.0 & 4.0 & 0.1 \\
\hline Financing of scientific development & 6.0 & 69.7 & 23.0 & 0.3 \\
\hline Costs of innovation & 30.0 & 60.0 & 8.6 & 0.4 \\
\hline Investment & 75.0 & 20.0 & 4.5 & 0.5 \\
\hline Capital investments for technical re-equipment and modernization & 83.0 & 10.0 & 6.1 & 0.9 \\
\hline
\end{tabular}

Source: data of $V$. Heyets [7].

In addition, over the years of its independence, Ukraine has failed to invert the social and economic, the appropriate transformation of politics of neoliberalism and neo-globalism [7], which 
predetermined a long recession and economic growth without development. Such economic systems, according to classification by D. Bell [2], are preindustrial, characterized by raw material orientation, low standards of living and little potential of endogenous growth. In contrast to other socioeconomic formations, neo-industrialization implies modernization and structural reformatting of the national economy, ensuring its sustainable development, improving the efficiency of utilization of all types of resources, their recycling, growth in the quality of life and the level of labor preservation, introduction of waste-free production and its environmental aspect, transition to renewable energy sources and organic agricultural production.

As noted by P. Sabluk, the establishment of an innovative model in the development of the agrarian sector of the economy is a systemic task whose solving is largely dependent on the role of the institution of agrarian science being the subject of innovation activity and a participant of the innovation process [20]. That is, agricultural science acts as a highly technological sector of the economy, which is based on innovation [18].

The experience of the main developed countries shows that now, in the era of the knowledge economy, the basic object of reproducibility in the economy is human capital, formed under conditions of the development of educational-scientific and socio-cultural processes, but limited by the individual capabilities and abilities. In this case, education ensures the quality of economic growth, and the history of civilization development does not include any example when a certain country became richer at the impoverished education, science, and culture [26]. According to the data from the World Bank, over 2000-2019, the share of scientists among the employed population increased, on average, in the EU-28 countries by 1.5 times, and in Bulgaria, Lithuania, Poland, Slovenia, and the Czech Republic - by more than 1.7 times (Table 2).

Table 2. Number of people engaged in R\&D and scientists per 1000 people of employed (aged 15-70) in selected countries, persons

\begin{tabular}{|l|c|c|c|c|c|c|c|c|}
\hline \multicolumn{1}{|c|}{ Country } & $\mathbf{2 0 0 0}$ & $\mathbf{2 0 0 5}$ & $\mathbf{2 0 1 0}$ & $\mathbf{2 0 1 3}$ & $\mathbf{2 0 1 5}$ & $\mathbf{2 0 1 7}$ & $\mathbf{2 0 1 8}$ & $\mathbf{2 0 1 9}$ \\
\hline EU-28 & 14.8 & 15.4 & 17.9 & 19.7 & 20.4 & 21.6 & 21.9 & 22.1 \\
\hline Bulgaria & 6.1 & 6.3 & 6.9 & 7.7 & 10.0 & 10.2 & 11.3 & 10.9 \\
\hline Czech Republic & 11.6 & 13.9 & 16.2 & 19.1 & 20.3 & 21.1 & 22.0 & 22.7 \\
\hline Estonia & 11.5 & 13.4 & 18.4 & 17.2 & 16.1 & 15.3 & 15.0 & 15.2 \\
\hline Germany & 18.1 & 18.9 & 21.3 & 22.3 & 23.4 & 24.0 & 24.1 & 24.2 \\
\hline Hungary & 11.9 & 12.8 & 14.6 & 15.1 & 13.5 & 13.9 & 18.0 & 18.2 \\
\hline Latvia & 8.9 & 10.0 & 11.1 & 11.9 & 13.0 & 13.1 & 13.9 & 13.8 \\
\hline Lithuania & 10.6 & 11.5 & 15.5 & 18.0 & 16.7 & 18.2 & 18.6 & 19.6 \\
\hline Poland & 8.9 & 8.9 & 8.5 & 9.5 & 10.0 & 14.9 & 16.5 & 16.3 \\
\hline Romania & 3.9 & 4.7 & 4.7 & 5.3 & 5.3 & 5.4 & 5.3 & 5.1 \\
\hline Slovakia & 10.6 & 10.1 & 12.2 & 12.0 & 12.0 & 13.4 & 14.1 & 14.3 \\
\hline Slovenia & 13.9 & 13.6 & 19.1 & 24.0 & 22.9 & 23.3 & 24.6 & 25.7 \\
\hline Spain & 12.8 & 14.8 & 19.4 & 19.6 & 19.1 & 19.0 & 19.3 & 18.8 \\
\hline Ukraine & 9.3 & 8.2 & 7.0 & 6.0 & 6.2 & 5.8 & 5.4 & 4.8 \\
\hline
\end{tabular}

Source: compiled and calculated by authors based on data from the State Statistics Service of Ukraine [14] and Eurostat [4].

Instead, in Ukraine, which had, in the early 1990s, one of the most powerful scientific and human potentials in the post-Soviet space, it demonstrates, at present, an annual tendency to degradation. Specifically, over 1990-2019, the number of scientific organizations' employees decreased by 3.9 times, compared to 2000 - by 2.0 times. Based on 1000 people employed in 2019, the number of performers of research works and researchers in Ukraine did not exceed 5 people, which is by 4.6 times less than in the EU-28, by 5.0 times less than in Germany, etc.

A change in the number of scientists is organically accompanied by the dynamics of the share $R \& D$ expenditures in GDP. Thus, one observes, on average, in EU-28 over 2000-2018, an increase in this indicator by 0.35 percentage points, in the Czech Republic -0.82 , in Estonia - 0.80, in Hungary 0.74 , etc. At the same time, Ukraine annually reduces the funding of science and now has one of the lowest levels in Europe $-0.47 \%$ of GDP (Table 3 ).

Moreover, out of total expenditures, $85.9 \%$ accounts for the internal current expenditures, with $45.9 \%$ being the cost of labor remuneration, which leads to an active degradation in the material and technical base and makes it impossible to carry out quality research and experimental studies.

In $2019,63.3 \%$ of total intramural R\&D expenditures in Ukraine were directed towards the area of technical sciences, $21.8 \%$ - natural sciences, and only $5.5 \%$ - to fund research in agricultural sciences (Figure 1). 
Table 3. Share of $R \& D$ expenditures in GDP in selected countries of the World, \%

\begin{tabular}{|l|c|c|c|c|c|c|c|}
\hline \multicolumn{1}{|c|}{ Region } & $\mathbf{2 0 0 0}$ & $\mathbf{2 0 0 5}$ & $\mathbf{2 0 1 0}$ & $\mathbf{2 0 1 3}$ & $\mathbf{2 0 1 5}$ & $\mathbf{2 0 1 7}$ & $\mathbf{2 0 1 8}$ \\
\hline EU-28 & 1.77 & 1.74 & 1.92 & 2.02 & 2.04 & 2.06 & 2.12 \\
\hline Bulgaria & 0.50 & 0.44 & 0.56 & 0.63 & 0.96 & 0.75 & 0.76 \\
\hline Czech Republic & 1.11 & 1.17 & 1.34 & 1.90 & 1.93 & 1.79 & 1.93 \\
\hline Estonia & 0.60 & 0.92 & 1.58 & 1.72 & 1.47 & 1.29 & 1.40 \\
\hline Germany & 2.41 & 2.44 & 2.71 & 2.82 & 2.91 & 3.02 & 3.13 \\
\hline Hungary & 0.79 & 0.92 & 1.14 & 1.39 & 1.36 & 1.35 & 1.53 \\
\hline Latvia & 0.44 & 0.53 & 0.61 & 0.61 & 0.63 & 0.51 & 0.64 \\
\hline Lithuania & 0.58 & 0.75 & 0.78 & 0.95 & 1.04 & 0.89 & 0.94 \\
\hline Poland & 0.64 & 0.56 & 0.72 & 0.87 & 1.00 & 1.03 & 1.21 \\
\hline Romania & 0.37 & 0.41 & 0.46 & 0.39 & 0.49 & 0.50 & 0.50 \\
\hline Slovakia & 0.64 & 0.49 & 0.62 & 0.82 & 1.17 & 0.88 & 0.84 \\
\hline Slovenia & 1.36 & 1.42 & 2.06 & 2.58 & 2.20 & 1.86 & 1.95 \\
\hline Spain & 0.88 & 1.10 & 1.35 & 1.27 & 1.22 & 1.20 & 1.24 \\
\hline Ukraine & $\mathbf{1 . 1 6}$ & $\mathbf{1 . 1 3}$ & $\mathbf{0 . 8 0}$ & $\mathbf{0 . 7 3}$ & $\mathbf{0 . 5 5}$ & $\mathbf{0 . 4 5}$ & $\mathbf{0 . 4 7}$ \\
\hline
\end{tabular}

Note: There are no data available at the Eurostat and World Bank databases for 2019.

Source: compiled and calculated by authors based on data from the State Statistics Service of Ukraine [14], Eurostat [4], and the World Bank [25].

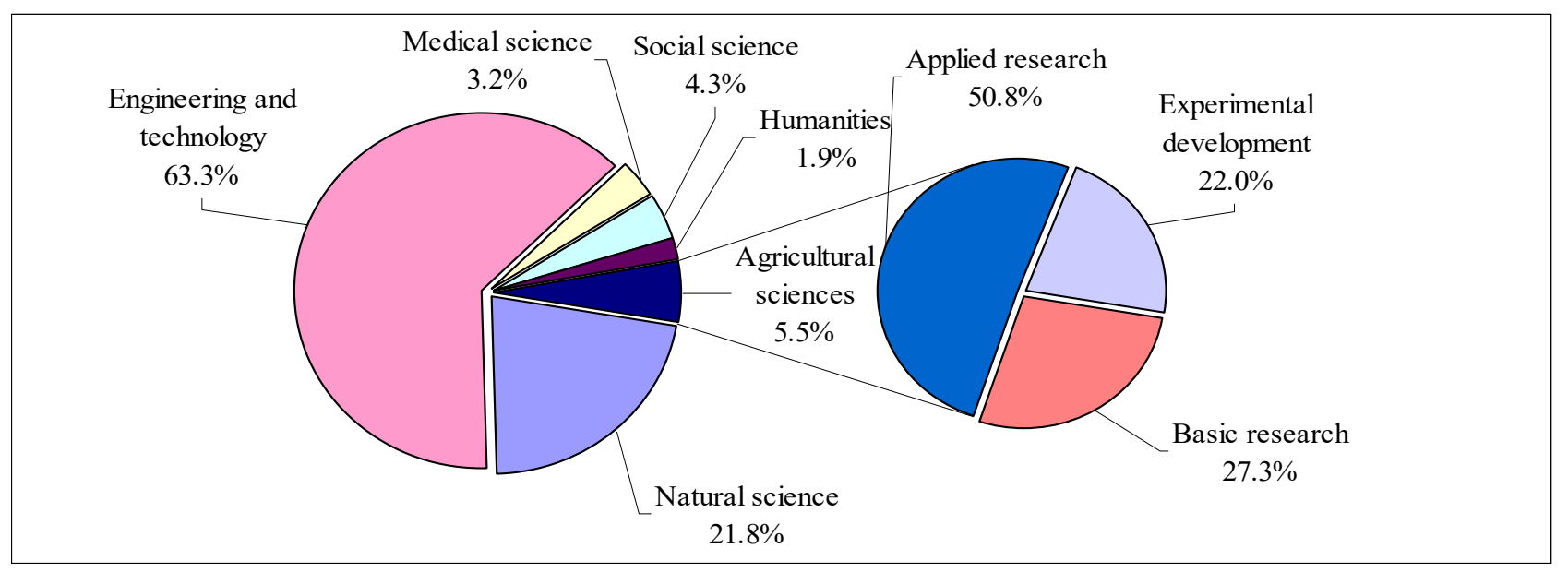

Figure 1. The structure of intramural R\&D expenditure by fields of science in Ukraine in 2019, \%

Source: compiled and calculated by authors based on data from the State Statistics Service of Ukraine [14].

Of the total expenditures, $21.8 \%$ were directed to basic research, $21.2 \%$ - to applied research, and $57.3 \%$ - to the experimental development. In the area of agricultural science, the share of funding for applied research was the highest (50.8\% in 2019), which is due to the need for variety sorting and hybridization.

It should be noted that the value of $R \& D$ expenditures not only characterizes the level of forming and realization of innovation potential, but also largely determines the formation of gross value added.

The results of regression analysis by least squares showed that the intramural $\mathrm{R} \& \mathrm{D}$ expenditure determines forming of $34.9 \%$ of the gross value added of the agrarian sector of economy (Table 4).

There is a significant correlation between the studied factors (on the Chaddock scale). The regression model is statistically significant by the Fcriterion at a confidence level of 0.01. The parameters of the regression model are also statistically significant by the t-test at a confidence level of 0.01 . The parameters of the regression equation indicate a direct positive impact of innovation potential on the forming of gross value added at the industry. At the same time, increasing of intramural $R \& D$ expenditures in the field of agricultural sciences by $1 \%$ leads to an average increase in the gross value added of the agrarian sector of economy by $0.4489 \%$.

The National Academy of Agrarian Sciences of Ukraine plays the main role in the area of scientific support to agroindustrial production. The result of the research funded from the State budget of Ukraine is that the scientists from the network created in 2011201510135 types of scientific and technical products, $48.6 \%$ of which are the results of basic research, $51.4 \%$ - applied studies. During 20142019 , the total number of newly created scientific and technical products increased by more than $10 \%$. (Table 5). 
Table 4. Results of regression analysis of the intramural $R \& D$ expenditure impact on the forming of gross value added of the agrarian sector of economy of Ukraine

\begin{tabular}{|l|l|}
\hline \multicolumn{1}{|c|}{ Parameter } & \multicolumn{1}{c|}{ Value } \\
\hline Regression equation & $Q=1740.6 \cdot R D E^{0.4489}$ \\
\hline Multiple correlation, $R$ & 0.59131 \\
\hline$R$-squared & 0.34965 \\
\hline Standardized $R$-squared & 0.31352 \\
\hline F-test & 9.67749 \\
\hline F-test significance & 0.00603 \\
\hline $\begin{array}{c}\text { Parameter "a" } \\
t \text {-statistics }\end{array}$ & 13.54665 \\
\hline \multicolumn{1}{|c|}{-statistics significance } & $7.00223 \cdot 10^{-11}$ \\
\hline $\begin{array}{c}\text { Parameter "b" } \\
t \text {-statistics }\end{array}$ & 3.11087 \\
\hline$t$-statistics significance & 0.00603 \\
\hline
\end{tabular}

Source: calculated by authors.

Table 5. Results of basic and applied research by scientific institutions at the National Academy of Agrarian Sciences of Ukraine, funded from the State budget in 2011-2019

\begin{tabular}{|l|c|c|c|c|c|}
\hline \multirow{2}{*}{ Type of a scientific-technical product } & \multicolumn{3}{|c|}{ Number of created scientific-technical products } \\
\cline { 2 - 5 } & $\mathbf{2 0 1 4}$ & $\mathbf{2 0 1 5}$ & $\mathbf{2 0 1 7}$ & $\mathbf{2 0 1 8}$ & $\mathbf{2 0 1 9}$ \\
\hline Databases & 200 & 147 & 292 & 199 & 167 \\
\hline Vaccines, diagnostics, therapeutic and prophylactic preparations & 5 & 34 & 12 & 8 & 4 \\
\hline Plants protecting tools & 6 & 16 & 15 & 5 & 4 \\
\hline Lines of agricultural plants & 402 & 300 & 1688 & 509 & 735 \\
\hline Mathematical models & 81 & 25 & 23 & 41 & 27 \\
\hline Methods & 251 & 315 & 139 & 108 & 85 \\
\hline New machinery (machines, equipment, models) & 38 & 105 & 32 & 33 & 29 \\
\hline New materials & 3 & 27 & 16 & 4 & 7 \\
\hline Breeds and types of animals, herd & 3 & 3 & 1 & 6 & 11 \\
\hline Plant varieties and hybrids & 198 & 296 & 143 & 181 & 89 \\
\hline Methods & 111 & 126 & 129 & 141 & 55 \\
\hline Theories, strategies, concepts & 72 & 98 & 80 & 82 & 83 \\
\hline Manufacturing technologies for animal protection & 22 & 18 & 3 & 0 & 0 \\
\hline Technologies, technological techniques & 228 & 329 & 146 & 200 & 134 \\
\hline Other & 475 & 1259 & 743 & 1042 & 895 \\
\hline \multicolumn{1}{|c|}{ Total } & 2095 & 3098 & 3462 & 2559 & 2325 \\
\hline including those resulting from & & & & 2482 & 1086 \\
\hline - basic research & 988 & 1538 & 1211 \\
\hline
\end{tabular}

Source: compiled and calculated by authors based on the annual report of the National Academy of Agrarian Sciences of Ukraine [1].

In this case, there was a rapid increase in the effectiveness of basic research, indicating growth of the innovation potential of the economy's agrarian sector. In 2017, compared to the previous 10 years, scientists created a record number of lines of agricultural plants $(14.1 \%$ larger than in total over 2011-2015). In the structure of the scientific and technical products, a significant share belonged to the newest databases, methods, procedures, production techniques, technologies and technological tools, varieties and hybrids of plants, etc.

One of the main effective indicators in the implementation of the innovative potential of science is dynamics in the number of registered intellectual property rights. Thus, the dynamics of the number of issued patents for invention generally confirm the tendencies in personnel and financial support to the scientific activities. In most innovation-oriented countries of the world, the results of patent work have significantly improved since 2001. In terms of the growth pace, China is a leading country, whose share in the total global result in 2019 amounted to $30.2 \%$ (Table 6).

As demonstrated by data from the "Ukrainian Intellectual Property Institute", the pace of research activity in 2005-2019 significantly decreased. Thus, in 2005, national applicants filed 3535 applications for inventions, 7156 for patents for utility models, 1750 for patents for industrial designs, 13184 for trademarks for goods and services. Of the total number of applications, $84.9 \%$ were filed by legal entities. By 2019, the number of applications for 
issuing law documents on the objects of intellectual property rights from national applicants increased due to a two-fold increase in the number of applications for trademarks for goods and services. The share of legal entities also increased by 5.1 percentage points. Among innovative-active legal entities, the greatest share belonged to educational institutions, which, according to the results of patent licensing work (by the number of obtained patents for inventions and utility models) in 2005-2019, outperformed by 2.6 times the scientific institutions, which negatively characterizes the status and dynamics of the transformations of the innovative potential of the national scientific field.

Table 6. Number of issued patents for invention in selected countries

\begin{tabular}{|l|c|c|c|c|c|c|c|c|}
\hline Region & $\mathbf{1 9 9 1 - 1 9 9 5}$ & $\mathbf{1 9 9 6 - 2 0 0 0}$ & $\mathbf{2 0 0 1 - 2 0 0 5}$ & $\mathbf{2 0 0 6 - 2 0 1 0}$ & $\mathbf{2 0 1 1 - 2 0 1 5}$ & $\mathbf{2 0 1 7}$ & $\mathbf{2 0 1 8}$ & $\mathbf{2 0 1 9}$ \\
\hline Australia & 58430 & 59159 & 64089 & 59492 & 95115 & 22742 & 17065 & 17010 \\
\hline Austria & 8686 & 6668 & 6208 & 6334 & 6211 & 1102 & 1189 & 1112 \\
\hline Canada & 69165 & 49903 & 61073 & 90842 & 112364 & 24099 & 23499 & 22009 \\
\hline China & 21920 & 31900 & 177372 & 482939 & 1189450 & 420144 & 432147 & 452804 \\
\hline France & 67992 & 63445 & 56241 & 57139 & 59119 & 11865 & 12249 & 13593 \\
\hline Germany & 83973 & 78277 & 80369 & 84194 & 66734 & 15653 & 16367 & 18255 \\
\hline Hungary & 8880 & 6962 & 6247 & 2757 & 3014 & 155 & 156 & 135 \\
\hline India & 7940 & 7923 & 11252 & 52167 & 25048 & 12387 & 13908 & 23578 \\
\hline Italy & 30639 & 46617 & 27900 & 53769 & 35067 & 4855 & 6424 & 8617 \\
\hline Japan & 408100 & 780173 & 610592 & 899345 & 1206693 & 199577 & 194525 & 179910 \\
\hline Poland & 15748 & 12010 & 10348 & 16772 & 13824 & 2904 & 2980 & 3042 \\
\hline Romania & 9604 & 7282 & 4493 & 3288 & 1926 & 407 & 363 & 357 \\
\hline Spain & 6700 & 9462 & 10320 & 12484 & 14332 & 2011 & 1760 & 1272 \\
\hline USA & 495396 & 680133 & 806688 & 875788 & 1354580 & 318829 & 307759 & 354430 \\
\hline Ukraine & 8868 & 24793 & 45520 & 19471 & 17434 & 2590 & 2469 & 2255 \\
\hline World & 1896251 & 2679900 & 2976200 & 4041700 & 5703700 & 1397900 & 1423000 & 1500900 \\
\hline
\end{tabular}

Source: compiled and calculated by authors based on data from the State enterprise "Ukrainian Institute for Intellectual Property" [24] and WIPO [29].

Despite the increasing effectiveness of basic and decline, which became especially noticeable in 2007 applied research at the National Academy of (Table 7). Agrarian Sciences of Ukraine, the number of intellectual property objects in 1996-2019 tends to

Table 7. Patent and licensing work of scientific institutions at the National Academy of Agrarian Sciences of Ukraine in 1996-2018, units

\begin{tabular}{|c|c|c|c|c|c|c|c|c|}
\hline Intellectual property object & $\begin{array}{c}1996- \\
2000\end{array}$ & 2000 & 2007 & 2009 & $\begin{array}{c}2011- \\
2015\end{array}$ & 2015 & 2018 & 2019 \\
\hline ventions & \multirow{2}{*}{$676 / 706$} & \multirow{2}{*}{$72 / 70$} & $322 / 297$ & $89 / 77$ & $222 / 222$ & $35 / 34$ & $29 / 28$ & $22 / 32$ \\
\hline odels & & & $35 / 21$ & $241 / 211$ & $1079 / 1041$ & $194 / 171$ & $209 / 184$ & $128 / 172$ \\
\hline Industrial sampl & N/A & $N$ & $\mathrm{~N} / \mathrm{A}$ & $N / A$ & $5 / 1$ & $0 / 0$ & $0 / 0$ & $0 / 0$ \\
\hline & $12 / 32$ & $0 / 0$ & N/A & N/A & $/ 14$ & $7 / 1$ & 4 & $12 / 5$ \\
\hline $\begin{array}{l}\text { plant hybrids, lines } \\
\text { tal components }\end{array}$ & 897 / 497 & $54 / 77$ & $261 / 396$ & $321 / 218$ & $842 / 994$ & $266 / 245$ & $186 / 345$ & $109 / 194$ \\
\hline $\begin{array}{l}\text { Bree } \\
\text { anim }\end{array}$ & 184 / 67 & $49 / 2$ & $10 / 4$ & $1 / 6$ & $5 / 4$ & $1 / 2$ & $0 / 0$ & $0 / 0$ \\
\hline $\begin{array}{l}\text { Copyright and Related Rights } \\
\text { (Business) }\end{array}$ & N/A & N/A & 41 & 41 & 208 & 42 & $32 / 29$ & $38 / 27$ \\
\hline Total & $\begin{array}{c}1769 / \\
1302 \\
\end{array}$ & $175 / 149$ & $669 / 755$ & $693 / 553$ & $\begin{array}{c}2392 / \\
2484 \\
\end{array}$ & $545 / 495$ & $464 / 590$ & $309 / 430$ \\
\hline Licensing agreements signed & 835 & 75 & 3318 & 4749 & 11392 & 1752 & 1227 & 1175 \\
\hline
\end{tabular}

Note: Before the oblique line - filed applications for obtaining documents for intellectual property objects; after the oblique linereceived documents for intellectual property objects. $N / A-$ no data available.

Source: compiled and calculated by authors based on the annual report of the National Academy of Agrarian Sciences of Ukraine [1]. 
In 2019, scientific institutions submitted 309 applications for the registration of objects of intellectual property rights, which is $43.3 \%$ less than in 2015 and is $53.8 \%$ less compared to 2007 . Of the number of submitted applications, $48.5 \%$ accounted for industrial property objects, $35.3 \%$ - new varieties, hybrids of plants, lines and parent components, transferred for variety sorting to the Ukrainian Institute of Plant Varieties Testing, $12.3 \%$ - objects of copyright and related rights.

It should be noted that there is a very negative tendency in the area of commercialization of the scientific developments at the National Academy of Agrarian Sciences of Ukraine. Over 2007-2019, the number of signed license agreements decreased by 2.8 times.

According to the O. Shubravska, such inconsistency between high innovative potential of the National Academy of Agrarian Sciences of Ukraine and low results of its utilization may indicate, first, the actual overstatement of the potential of the economy's agrarian sector; second, the lack of market demand for the commercialization of innovations in general, and especially domestic producers; third, the lack of the state support for innovation activities in the agrarian area [22]. The main types of innovative products, which are now in demand in the domestic market, are seed material, soil tillage technologies, biopreparations, plant growth stimulators, certain technological solutions, etc. [12]. The low innovation potential is inherent in the industrial samples of agricultural machinery made in Ukraine, mineral fertilizers, as well as theoretical and applied results of agricultural economics research. At the same time, high potential for industrial implementation is demonstrated by the plant varieties of domestic selection, especially winter wheat, spring barley, triticale, beans, chickpeas, all cereals, flax, castor, mustard, individual hybrids of sunflower and regional varieties of fruit and berry crops [30].

As noted by the authors of the National Report "Innovative Ukraine 2020", in 2014 the innovative activity of agricultural enterprises did not exceed 15 $\%$, and in the most efficient ones was about $57 \%$ in crop production and about $30 \%$ in livestock breeding [8]. In addition, small and medium enterprises, except large integrated business entities, were limited in implementing their own innovation potential, given the lack of free funds, low profitability, and the lack of specialists capable of generating innovations.

According to the data from the National Academy of Agrarian Sciences of Ukraine, the volume of the actual introduction of innovative advancements by the scientists at the Academy into agricultural production during 2000-2019 was insignificant. In particular, the number of agricultural enterprises that implemented innovations decreased by more than twice over the period studied. In the total number of legal entities in the agrarian sector of economy (taking into consideration private farms), their share decreased from 1.9 to $1.3 \%$ (Table 8 ).

Table 8. Implementation of innovation advancements at the National Academy of Agrarian Sciences of Ukraine in 2000 2019

\begin{tabular}{|c|c|c|c|c|}
\hline \multirow{2}{*}{ Year } & \multicolumn{2}{|c|}{$\begin{array}{c}\text { Number of agricultural enterprises in } \\
\text { Ukraine }\end{array}$} & \multicolumn{2}{c|}{$\begin{array}{c}\text { Agricultural enterprises that implemented } \\
\text { innovations }\end{array}$} \\
\cline { 2 - 5 } & total & $\begin{array}{c}\text { excluding private } \\
\text { farms }\end{array}$ & units & $\begin{array}{c}\text { share in total number, } \\
\text { \% }\end{array}$ \\
\hline 2000 & 66793 & 31422 & 1298 & 1.9 \\
\hline 2003 & 59923 & 16907 & 2928 & 4.9 \\
\hline 2007 & 58387 & 14912 & 920 & 1.6 \\
\hline 2010 & 56493 & 14767 & 1087 & 1.9 \\
\hline 2011 & 56133 & 14645 & 1203 & 2.1 \\
\hline 2013 & 49046 & 14878 & 593 & 2.2 \\
\hline 2014 & 46199 & 13115 & 636 & 1.3 \\
\hline 2015 & 45379 & 13076 & 610 & 1.4 \\
\hline 2017 & 45558 & 11421 & 667 & 1.3 \\
\hline 2018 & 49208 & 16044 & 654 & 1.4 \\
\hline 2019 & 48504 & 16052 & & 1.3 \\
\hline
\end{tabular}

Source: compiled and calculated by authors based on data from the State Statistics Service of Ukraine and the annual report of the National Academy of Agrarian Sciences of Ukraine [1].

The development of innovations transfers in 20022013 was significantly contributed to by the activities of regional scientific support centers of agroindustrial production; they, however, could not fully implement the innovative model of the agrarian sector development in Ukraine, which led to their elimination. The issue is also complicated by the low quality of innovative projects developed by the structural divisions of the National Academy of Agrarian Sciences of Ukraine, which not only leads to an understatement of the cost of innovative products but actually makes them uncompetitive. 
One of the main reasons for this is a low wage, which reduces the interest of creative staff in employment in the innovation sphere, contributes to the outflow of young scientific staff and specialists from scientific establishments and educational institutions to businesses (Table 9).

Table 9. Average monthly rated wage of staff employees in Ukraine in 1996-2019, USD/person

\begin{tabular}{|c|c|c|c|c|c|}
\hline \multirow{2}{*}{ Year } & \multirow{2}{*}{$\begin{array}{c}\text { Average in } \\
\text { the economy }\end{array}$} & \multicolumn{3}{|c|}{ Type of economic activity } & $\begin{array}{c}\text { Employees at the scientific } \\
\text { establishments of the National Academy } \\
\text { of Agrarian Science }\end{array}$ \\
\hline 1996 & 68.87 & 37.72 & 78.71 & 65.05 & 80.35 \\
\hline 1998 & 62.46 & 36.33 & 75.93 & 52.26 & 58.79 \\
\hline 2000 & 42.28 & 20.40 & 55.70 & 28.68 & 34.01 \\
\hline 2003 & 86.64 & 39.38 & 106.89 & 63.76 & 66.76 \\
\hline 2007 & 267.52 & 145.15 & 344.75 & 209.90 & 243.17 \\
\hline 2009 & 244.63 & 154.79 & 328.06 & 206.77 & 208.70 \\
\hline 2010 & 282.14 & 180.20 & 362.16 & 240.06 & 251.78 \\
\hline 2011 & 330.46 & 224.79 & 410.41 & 260.93 & 297.33 \\
\hline 2012 & 378.67 & 253.53 & 464.15 & 316.61 & 346.89 \\
\hline 2013 & 408.48 & 284.00 & 503.44 & 337.80 & 247.43 \\
\hline 2014 & 292.77 & 208.30 & 359.06 & 230.93 & 132.21 \\
\hline 2015 & 192.04 & 143.74 & 227.61 & 143.38 & 111.97 \\
\hline 2016 & 202.85 & 153.26 & 239.48 & 147.51 & 157.65 \\
\hline 2017 & 267.10 & 216.61 & 308.76 & 220.22 & 181.17 \\
\hline 2018 & 325.91 & 263.45 & 377.16 & 258.86 & 227.32 \\
\hline 2019 & 406.14 & 338.08 & 450.72 & 314.75 & \\
\hline
\end{tabular}

Note: Conversion into US dollars was made to ensure the comparability of data based on the official courses of National Bank of Ukraine.

Source: compiled and calculated by authors based on data from the State Statistics Service of Ukraine and the annual report of the National Academy of Agrarian Sciences of Ukraine [1].

The situation particularly worsened in 2015-2016 when salaries of the scientific and pedagogical employees were not indexed. In 2019, its level in education was $22.5 \%$ lower than the average indicator in the economy of Ukraine.

The average monthly rated wage of staff members at the scientific institutions of the National Academy of Agrarian Sciences of Ukraine declined in 2019, compared to 2013, and was 1.8 times lower than the average Ukrainian level and 1.4 times lower than in the field of education.

\section{Discussion}

The opinion of $\mathrm{V}$. Vergunov is reasonable when arguing that the scientific potential of the agricultural science of Ukraine can enable the attainment of the world level of research in plant and animal breeding, advanced biotechnologies, environment preservation, etc. Results of research could make it possible to produce in Ukraine annually about $80-100$ million tons of grain, 9-10 million tons of oilseeds, to double the volume of livestock production, to build the image of Ukraine as a world's granary [27].

In general, forming the potential of innovative development of the agrarian sector of economy should be based on considering the set of "5-s" devised by G. Kaletnik, G. Zabolotnyi and S. Kozlovskyi: scientific basic research, scientific applied research, scientific and technical advancements, scientific establishments, which, based on their information, personnel, material infrastructure, conduct scientific and technical activities, as well as specialized higher education institutions that train specialists for both science and production [13]. At the same time, the lack of development of the institutional system of information support for innovation activities, as well as information secrecy of most business entities in the agrarian sector of the economy, do not provide a proper basis for the formation of demand and expansion of market capacity of innovative advancements within national production.

\section{Conclusions}

Under market conditions, the innovation potential underlies the economic growth and inclusive sectoral development, while its effective implementation defines the level of competitiveness including not only products but also the entire national economy in the world arena. At present, the economy of Ukraine faces a civilization choice: either to proceed along the way of neo-industrialization and food independence or become a resource-intensive raw appendage of more developed countries.

In the agrarian sector of economy, during the years of Ukraine's independence, not only was there a 
transformational progression to the market, whereby the forms and methods of management changed but de-industrialization did take place, especially at small and medium-sized agricultural enterprises; the agroindustrial production came unstuck. Liberalization and low pace of economic development have laid a solid foundation for the degradation of innovation processes, with globalization contributing to the replacement of national science-intensive innovative products with foreign ones, resulting in further destruction of the domestic science and technology, the lack of gross value added, and the outflow of staff beyond the borders.

Analysis of the status of the innovative potential in the development of the agrarian sector has revealed its decline during 1996-2019 in terms of the basic indicators, while its elements were not competitive even in the domestic market. At present, there is an almost completely lost scientific research potential of livestock, poultry, agricultural mechanization, reclamation, and, to a large extent, the potential of technical and technological support of processing and storage of agricultural produce. There is a demand in the market mainly for varieties and hybrids of the domestic selection of grain, legumes, cereals, vegetable, fruit and berry crops, while at the same time there is a need to develop the selection of bioenergy crops, sugar beets, industrial crops, grapes, etc. In addition, the main role in the scientific support of agroindustrial production and coordination of agroeconomic research should belong to the National Academy of Agrarian Sciences of Ukraine.

We think that it is necessary to reform the state agrarian and economic policy, re-orienting them to the neo-industrial paradigm of the innovative development of integration relations in the agrarian sector of the economy, to transform institutional environment for innovative entrepreneurship support and innovation transfer, to establish a holistic innovative system of agroindustrial production development at the national and regional levels, to implement an effective organizational-economic mechanism of state support and regulation of innovation activities in the agrarian sector of the economy, to provide continuity of the chain "science-production-science", especially when it comes to making employees at the educational institutions interested in the final results of their work, as well as engaging domestic agricultural producers in implementing the innovative developments from national producers.

\section{References}

[1]. Adamchuk, V.V., Huzevatyi, O.Ye. \& Kuzminskyi, V.V. (2020). Zvit pro diialnist Natsionalnoi akademii ahrarnykh nauk Ukrainy za 2019 rik [Annual Report of the National Academy of Agrarian Sciences of Ukraine for 2019]. Kyiv: Ahrarna nauka.

[2]. Bell, D. (1999). The Coming of Post-Industrial Society: A Venture in Social Forecasting. New York: Basic Books. [ISBN: 9780465097135]

[3]. Dzyubina, A. V. (2008). Disclosure of the concept of «innovative potential» and definition of its components. Visnyk NY «Lvivska politechnika»Bulletin of $N U$ «Lviv Polytechnic, 628, 72-77.

[4]. Eurostat (2020). Database. Retrieved from: https://ec.europa.eu/eurostat/data/database [accessed: 15 January 2021].

[5]. Fedonin, O. S., Riepina, I. M., \& Oleksyk, O. I. (2005). Potentsial pidpryiemstva: formuvannia ta otsinka [Enterprise potential: formation and evaluation]. KNEU, Kyiv, 261 p.

[6]. Heathfield, D. F., \& Wibe, S. (1987). The CES Function. In An Introduction to Cost and Production Functions (pp. 92-104). Palgrave, London.

[7]. Heiets, V. M. (2009). Suspilstvo, derzhava, ekonomika: fenomenolohiia vzaiemodii ta rozvytku [Society, state, economy: phenomenology of interaction and development]. Kyiv [in Ukrainian].

[8]. Heyets, V.M. (Ed.). (2015). Innovative Ukraine 2020: National Report. Kyiv: National Academy of Sciences of Ukraine. (in Ukrainian). [ISBN: 978-96602-7615-4].

[9]. Babayev, V. M., Sukhonos, M. K., Dymchenko, O. V., Tararuiev, I. O., Yesina, V. O., Rudachenko, O. O., ... \& Beztsinna, Z. P. (2021). Potential of business entities: essence, assessment and role in national development: collective monograph. Sofia: VUZF Publishing House "St. Grigorii Bogoslov", 79.

[10]. Gritsenko, A. (2016). The formation of informationnetwork economy as a fundamental process of evolution of modern civilization. History, Problems and Prospects of Development of Modern Civilization, 181.

[11]. Hrytsulenko, S. I. (2020). Analiz dynamiky rozvytku ratsionalizatorstva i vynakhidnytstva $\mathrm{v}$ Ukrayini. Problemy ékonomyky, (2 (44)), 82-90.

[in Ukrainian]. https://doi.org/10.32983/2222-0712-2020-2-82-90

[12]. Hutorov, A. O., Lupenko, Y. O., Posylaiev, V. V., Dorokhov, O. V., \& Yermolenko, O. A. (2019). Economic basis of forming and implementation of the biofuel production potential in Ukraine. Bulletin of the Transilvania University of Brasov. Forestry, Wood Industry, Agricultural Food Engineering. Series II, 12(1), 43-58.

https://doi.org/10.31926/but.fwiafe.2019.12.61.1.4 
[13]. Kaletnik, GM, Zabolotnyi, GM, \& Kozlovskyi, SV (2011). Innovative models of strategic economic potential management within contemporary economic systems. Actual problems of economy, 118 (4), 3-11.

[14]. Kuznietsova, M.S. (Ed.). (2020). Scientific and Innovative Activity of Ukraine. Statistical Yearbook for 2019. Kyiv: State Statistics Service of Ukraine.

[15]. Malik, M., Shpykuliak, O., Nepochatenko, O., Nepochatenko, V., Ptashnyk, S., \& Tretiakova, S. (2019). Formation of effective organizational and economic environment of innovative support of enterprise competitiveness in Ukraine. In Proceedings of the 33rd International Business Information Management Association Conference, IBIMA 2019: Education Excellence and Innovation Management through Vision 2020 (pp. 332-342).

[16]. Shpykulyak, O. H., \& Gritsaenko, M. I. (2016). Scientific support for innovation development of agrarian sector. Business Inform, (4), 143-149.

[17]. Moskaliuk, K. (2012). Theoretical bases of innovative potential of agrarians phere of Ukraine. Naukovi praci Kirovohradskoho natsionalnoho tehnichnoho universytetu. Ekonomichni nauky, (22), 2.

[18]. Prysiazhniuk, M.V., Petrychenko, V.F. \& Volodin, S.A. (2013). Kontseptualni zasady innovatsiinoinvestytsiinoho rozvytku Natsionalnoi akademii ahrarnykh nauk Ukrainy [The Conceptual Patterns of Innovative and Investment Development of the National Academy of Agrarian Sciences of Ukraine]. Ekonomika APK, 4, 3-22. (in Ukrainian).

[19]. Ricardo, D. (2015). On the Principles of Political Economy, and Taxation. Cambridge University Press. https://doi.org/10.1017/CBO9781107589421

[20]. Sabluk, P. (2011). Reforms of rural areas and directions of innovational activity in the agroindustrial complex of the Ukraine. Economy of region, 1(4), 257-262. https://dx.doi.org/10.17059/2011-4-27

[21]. Schumpeter, J. A. (2017). The Theory of Economic Development: An Inquiry into Profits, Capita I, Credit, Interest, and the Business Cycle. Routledge. https://doi.org/10.4324/9781315135564

[22]. Shubravska, O. (2012). Innovacijnyj rozvytok aghrarnogho sektora ekonomiky Ukrajiny: teoretykometodologhichnyj aspekt [Innovative development of the agricultural sector of Ukraine: Theoretical and methodological aspects]. Ekonomika Ukrainy, 1, 27-35.
[23]. Sirtseva, S. V. (2008). Innovative potential as a component of the economic potential of an agricultural enterprise. Ukrainian Black Sea region agrarian science, (4), 47.

[24]. The State Enterprise "Ukrainian Intellectual Property Institute" (2019). Statistics, Plans, Reports.

Retrieved from:

https://ukrpatent.org/en/articles/statistics [accessed: 25 January 2021].

[25]. The World Bank (2020). World Development Indicators. Retrieved from:

https://databank.worldbank.org/source/worlddevelopment-indicators [accessed: 25 January 2021].

[26]. Nosovets, O., \& Voloshchuk, L. (2019). Innovative Potential In The Context of Determining The Innovative Activities Results of Industrial Enterprises. New Stages Of Development Of Modern Science In Ukraine And Eu Countries, 312. https://doi.org/10.30525/978-9934-588-15-0-39

[27]. Vergunov, V.A. (2019). Scientific Bases of Innovative Development of Agrarian Science at Regional Level. Bulletin of Agricultural Science, 97(5), 69-75.

https://doi.org/10.31073/agrovisnyk201905-09

[28]. Volodin, S. A., \& Chekamova, O. I. (2017). Teoretychni zasady formuvannia i realizatsii innovatsiinoho potentsialu $\mathrm{v}$ rozvytku ekonomiky [Theoretical bases of formation and realization of innovative potential in development economy]. Ekonomika APK, (5), 65-72.

[29]. World Intellectual Property Organization (2020). WIPO Statistics Database. Retrieved from: https://www3.wipo.int/ipstats/index.htm?tab=patent [accessed: 27 January 2021].

[30]. Zakharchuk, O. V., Lupenko, Y. O., Hutorov, A. O., \& Dorokhov, O. V. (2019). Economics of development of the seed-growing in Ukraine. Bulletin of the Transilvania University of Brasov. Forestry, Wood Industry, Agricultural Food Engineering. Series II, 12(2), 127-136. https://doi.org/10.31926/but.fwiafe.2019.12.61.2.11

[31]. Zubko, T., Kovshova, I., Ilchenko, N., Laptieva, V. \& Vavdiichyk, I. (2021). Evaluation of innovative Activity of Enterprises in the Conditions of European Integration. Eastern-European Journal of Enterprise Technologies, 3, 63-73.

https://doi.org/10.15587/1729-4061.2021.235950 